\title{
Freire: epäilyn ja kritiikin etiikka
}

\author{
Juha Suoranta
}

Jos kysytään, kuka on maailman tunnetuin urheilija, aika moni osaa vastata Muhammed Ali tai Péle tai Michael Jordan. Jos sitten kysytään tunnetuinta kasvatusajattelijaa, luulen, että vastaukset eivät ole yhtä ilmeisiä - ellei sitten pidä Jeesusta kasvattajana Jumalan armosta. Yksi nimi Jeesuksen ohella saatetaan kuitenkin tuntea: Paulo Freire.

$\mathrm{P}_{\mathrm{r}}$ uolitoista vuosikymmentä sitten julkaistussa romaanissa Gerdt Bladhin tuho, siis vähän ennen nk. markkinavoimien ensimmäistä rynnäkköä ja paljon ennen toista, teknokapitalistista vallankumosta, Christer Kihlman kirjoittaa enteellisesti:

"Kukaan ei selvästi tajunnut, minne oltiin menossa, sillä tulevaisuutta ei voi ennustaa. Useimmat kieltäytyivät ylipäänsä tunnustamastakaan, että jotakin ratkaisevaa oli tapahtumassa... Mutta jossakin kyti kauhu, kaikille yhteinen, vaistonvarainen tai tiedostamaton... Mielipiteenmuodostus oli siirtynyt konservatiivisille voimille, joita todellisuuden analysoiminen oikealla, joskin kenties epämiellyttävällä tavalla kiinnosti paljon vähemmän, kuin niiden oman mielipiteitä muovaavan valta-aseman säilyttäminen tarjoilemalla yleisölle juuri sellaisia siloiteltuja ja hampaattomia kannanottoja kuin se halusi saada.

Sokrateen määrittelemä totuus oli huonossa huudossa. Sokrateen määrittelemä mielistely oli vallalla.

Poliittisten puolueiden välinen alkuperäinen ero oli lakannut olemasta... Pinnalla oli hys- teerinen nälkä, pikku-uudistusten, merkityksettömien viimeisten uutuuksien nälkä, halu kokea jotakin erilaista, joka ei ollut vaarallista tai oli juuri sopivan vaarallista, siis vaihtelua. Pohjalla oli vimmatun epätoivoinen vastarinta, mitä tahansa todellista muutosta vastaan, mikä voisi uhata olemassaolevaa."1

Mitä tekemistä suomalaisen kirjailijan ja brasilialaisen filosofin teksteillä on keskenään? Lyhyesti sanoen molemmilla on älyllisen kysyvä, utelias ja samalla epäilevä suhde todellisuuteen. Heidän tekstinsä ovat kriittisessä suhteessa valistuksen projektiin ja niitä luonnehtii sekä epäilyn lahja että alttiiksi asettumisen etiikka. Kihlmanin ja Freiren tekstien epäilystä ja etiikkaa voisi kuvata realistiseksi. Realistinen ajattelu tarkoittaa, että enemmän kuin tieto-oppiin tai ontologiaan, kasvatuksen käytännöllinen ja käsitteellinen maailma perustuvat etiikkaan. Eettinen realismi on luonteeltaan yleisinhimillistä eikä missään mielessä näyttäydy vain tieteeksi kutsutulla inhimillisen toiminnan alueella. Eriaikaisten ja -paikkaisten ajattelijoiden vertailu saattaa vaikuttaa mielivaltaiselta. Jos kuitenkin haluaa nähdä yleismaailmallisesti ja säilyttää toivon huomisesta, 


\section{N Ä K Ö K UL M I A}

kuten kasvattajalle on uskoakseni välttämätöntä, on myös metodisesti uskottava perheyhtäläisyyteen yhtenä tutkimisen ja näkemisen tapana.

$F^{\prime}$ reireä pidetään yleisesti viime vuosisadan yhtenä keskeisimmistä kasvatusajattelujoista. Freiren merkitys on ollut kahtalainen. Toisaalta hän on luonut synteettisen kasvatusfilosofisen ajatusjärjestelmän, jonka merkityksestä on kirjoitettu ja kirjoitetaan jatkuvasti lukuisia kommentaareja, esityksiä ja tulkintoja. Toisaalta Freire tunnetaan erityisen opetusmetodisen kehyksen ja pedagogiikan kehittäjänä. Vapautuksen pedagogiikkana tunnettua järjestelmää on käytetty ja käytetään maailmanlaajuisesti erilaisissa kasvatuksellisissa interventioissa ja erityisesti lukutaito-ohjelmissa.

Samoin kuin kirjoittajaansa, myös ensimmäistä kasvatusfilosofiansa kokonaisesitystä Sorrettujen pedagogiikkaa pidetään perustellusti yhtenä 20 . vuosisadan kaikkein tärkeimmistä kasvatustieteellisistä ja kasvatusfilosofisista teoksista. Teoksella on oma syntyhistoriansa, intellektuaalinen ja reaalihistoriallinen juuristonsa. Sen kehitelmistä löytää rakenne- ja sisällöllisiä yhtäläisyyksiä koko Platonin jälkeiseen sivistyshistoriaan. Sen lukeminen palauttaa monia uusina pidettyjä kasvatustieteellisiä innovaatioita historiallisiin ja teoreettisiin yhteyksiinsä ja antaa niille kriittisen arviointiperusteen. Sorrettujen pedagogiikka kuuluu niiden kirjojen joukkoon, Marxin, Freudin, Deweyn tai vaikkapa Frommin tekstien ohella, jotka antavat lukijalleen mahdollisuuden päästä osalliseksi kriittisen valistuksen perinteestä. Freiren ajattelu on poliittista sanan kirjaimellisessa merkityksessä. Siksi ei ehkä olekaan ihmeellistä, että Freiren pääteos odottaa edelleen suomentamista. Asian voi ymmärtää tarkastelemalla sekä teoksen julkaisuajankohdan suomalaista reaalipolitiikkaa että tiedepolitiikkaa. Reaalipoliittisesti nousee keskeiseksi suomalaisen koulutuspolitiikan suunnitteluhakuinen pitkälinja, jossa ei liennyt suurta sijaa vapautta korostaville kasvatusaatteille.

Tiedepoliittisessa tarkastelussa toisaalla on suomalaista filosofiaa hallinnut analyyttinen koulukunta, jonka tutkimusintressissä on ollut vain niukasti tilaa elämismaailmallisille, voisi sanoa elävän filosofian, kysymyksille, joita Freirekin tuotannossaan tarkastelee. ${ }^{2}$. Toisaalla on kasvatustieteellinen oppineisuus, joka laajasti ottaen on haettu aivan toisista kuin kriittisen yhteiskuntatieteen lähteistä, nimittäin psykologiatieteen aikakaudesta toiseen vaihtelevista suuntauksista.

Vaikka onkin niin, että Freire on Sorrettujen pedagogiikan jälkeen tarkistanut, korjannut ja osin ehkä muuttanutkin näkemyksiään, hänen ajattelunsa ymmärtäminen ilman tämän teoksen ymmärtämistä on mahdotonta.

Sorrettujen pedagogiikan, ja Freiren profetiaalisen ajattelun yleensä, keskeisteemat käsittelevät tulevaisuutta, tulevaisuuden maailmaa, yhteiskunnallista ja yksilöllistä muutosta ja muutoksen edellytyksiä, hyvää yhteiskuntaa ja parasta mahdollista kasvatusta, sosiaalista oikeudenmukaisuutta ja yhdenvertaisuutta, yhteiskunnallista ja kasvatuksellista konservatismia ja sen vastavoimana kasvatuksellisen toivon ajatusta. Sanalla sanoen kaikkia niitä kysymyksiä, jotka ovat pohdituttaneet kaikkia merkittäviä kasvatusteoreetikoita kaikkina aikoina kaikissa paikoissa.

Freiren perusteoksessaan ja muualla esittämiä kysymyksenasetteluja pidetään tänään ajankohtaisempina kuin koskaan. Kaikki ne erivertaistavat seikat, epäoikeudenmukaisuus ja julma kohtelu, joita Freire näki ja koki elämässään, ovat voimakkaammin todellisia tänään kuin koskaan aikaisemmin; yhteiskunnallinen eriarvoisuus vain puetaan eufemismeihin, joista muodostuu annettua otettua ja itsestäänselvää todellisuutta. 
Freiren teksteihin on olemassa lukuisia lukutapoja, joiden muotoamiseen ja tulkintaan hän itsekin aktiivisena kirjoittajana ja keskustelijana osallistui. Toisaalla ovat romanttiset tulkinnat, jotka tekevät Freirestä syrjäytettyjen ja sorrettujen pyhimyksen. Toisaalla taas teknologiset lukutavat, jotka helppohintaisesti omaksuvat Freiren peruskäsitteitä käyttääkseen niitä omiin, Freirelle jokseenkin vieraisiin, tarkoituksiin. Vielä ovat ne, joissa pyritään arvioimaan Freiren perintöä kriittisesti, kehitellään sitä eteenpäin kontekstuaalisesti soveltaen, mutta pidetään silmämääränä Freiren ydinteemoja.

Freire on yksi viimeisistä kokonaisajattelijoista, joka ei halua tehdä ajattelulleen väkivaltaa paaluttamalla kasvatuksen kysymyksiä omaksi kaikkivoipaiseksi maailmakseen tai pelkistämällä tieteeksi nimitettyä kasvatusajattelua koulunpitoa koskeviksi erityiskysymyksiksi. Pikemminkin Freire haluaa osoittaa koulua ja kasvatusta koskevien kysymysten elimelliset kytkennät yleisiin yhteiskuntafilosofisiin ja poliittisiin kysymyksiin.

$\mathrm{F}$ reiren ajattelu on syntetisoivaa ja kokonaisvaltaista; se seurustelee kasvatuksen ja yhteiselämän ikuisten kysymysten kanssa. Siten se kuuluu ajatteluperinteeseen, jota Michel Foucault'n sanoin voi luonnehtia nykyisyyden ontologiaksi totuuden analytiikan vastinparina. Tässä perinteessä kysytään "Mikä on ajankohtamme? Mikä on nyt mahdollisten kokemusten alue?" Foucault'n sanoin jatkaakseni: "voidaan valita joko kriittinen filosofia, joka esittäytyy totuutta yleensä koskevana filosofisena analytiikkana, tai voidaan valita kriittinen filosofia, joka muotoutuu oman itsemme ontologiaksi, nykyisyyden ontologiaksi."3

Ei ole vaikeaa sijoittaa Freiren kasvatusfilosofiaa jälkimmäisen, kriittisen, tai elävän, filosofian maastoon. Freiren ajattelu, hänen puheensa, kirjoituksensa, keskustelunsa ja teoksensa ovat poliittista taistelua Kihlmanin mainitsemia yhteiskunnallisia vitsauksia - uusliberalistista kauhun tasapainoa, konservatiivisia voimia ja median levittämiä näennäisuudistuksia - vastaan. Freire käy sanan voimalla kamppailua yhteiskunnallista, joka on yhtä kuin kasvatuksellista, apatiaa vas- taan. Hän kamppailee sosiaaliseen omaantuntoon kohdistuvaa muistinmenetystä vastaan.

Freiren ajattelu ei kuitenkaan ole vain vastakertomusten luomista. Se on myös toivon kertomusten kirjoittamista. Freire muistuttaa kasvatuksellisista periaatteista, joilla on mahdollista luoda ihmisyhteiskunta; hän allekirjoittaa Marxin Feuerbach-teesinään esittämän ajatuksen: "Filosofit ovat vain eri tavoin selittäneet maailmaa, mutta tehtävänä on sen muuttaminen."4 Ja muuttamista siinä olisikin.

\section{Viitteet}

1 Christer Kihlman, 1987, Gerdt Bladhin tuho, Tammi, ss. 5-7. Kihlman on jatkanut modernisaatiokriittistä projektiaan vast'ikään kirjoittamassaan monologissa Vastaus on ei, joka Helsingin kaupunginteatterin lisäksi on esitetty radioteatterissa. Molemmissa monologin esitti Antti Litja.

2

Tämä filosofian tila näkyy erityisesti filosofian oppituolien täytöissä analyyttisen filosofian edustajilla (ks. Ilkka Niiniluodon katsaus "Filosofia Suomessa" teoksessa Nordin, Svante, Filosofian historia, Pohjoinen, 1999, ss. 491-546).

3 Michel Foucault, 1995, Kant ja moderni filosofia 3 nykyisyyden ontologiana. Teoksessa Koivisto, J., Mäki, M. \& Uusitupa, T. (toim.) Mitä on valistus? Tampere: Vastapaino, s. 260. (Teksti löytyy englanniksi esim. teoksesta Michel Foucault, 1997, The Politics of Truth. New York: Semiotext, otsikolla What is Revolution?)

4 Karl Marx \& Friedrich Engels, 1978, Valitut teokset, osa 2. Moskova: Kustannusliike Edistys, s. 66.

Juha Suoranta esitti edellä olevat näkemyksensä vastaväittäjän alkupuheena Aino Hannulan väitöstilaisuudessa 9. kesäkuuta Helsingin yliopistossa.. 